\title{
HasanuddinLawReview
}

\section{A Comparison Approach in Corruption Eradication: An Empirical Examination}

\author{
Mispansyah \\ Faculty of Law, Lambung Mangkurat University, Indonesia. E-mail: ipan.shmh@gmail.com
}

\section{ARTICLE INFO}

Keywords:

Corruption; Criminal Law;

Islamic Law; Legal Culture

How to cite:

Mispansyah. (2018). “A

Comparison Approach in

Corruption Eradication: An

Empirical Examination,"

Hasanuddin Law Review,

4(2): 219-232

DOI:

10.20956/halrev.v4i2.1077

\begin{abstract}
Corruption in Indonesia is increasingly structured and systemic. Worse yet, the corruption was fertile in sub-law enforcement agencies. This paper analyzes why corruption is so systemic in the legal system in Indonesia and how solution of Islam in eradicating corruption. This research was a normative-legal research. The results indicate that corruption occurred systemically in Indonesia due to secularization and capitalization in understanding the living system as embraced by the Republic of Indonesia, which resulted in bad law system both the substance, structure and legal culture, and bad people). The solution of Sharia Islam to eradicate corruption by creating a devotion of community (law awareness) based on religious values. In addition, with a decent salary system, appropriate penalties, the implementation of reverse evidence system and the exemplary leadership, corruption problems can be overcome and a clean government can be realized.
\end{abstract}

Copyright (C) 2018 HALREV. All rights reserved.

\section{Introduction}

The problem of corruption in Indonesia is increasingly acute, like a cancer that spreads almost in all layers of society, corruption gets worse in the executive (the government), judicative (judicial), as well as legislative (lawmakers). Corruption has been systematized in Indonesia, ranging from the administration (identity card, certificate, drive license) to policy-making and leaders vote in this country must be through corruption. Worse yet, the corruption was fertile in sub-law enforcement agencies. These initiatives reflect a growing academic and policy consensus that corruption is high in developing countries, and is costly. ${ }^{1}$ The growing policy activism that conditions international assistance on corruption outcome, in turn, reflects a belief that given the right incentives politicians, bureaucrats and civil society in these countries can reduce corruption.

The latest case of corruption, E-KTP involving executive and legislative members, corruption of E-KTP budget of Rp 5.9 trillion involves tens of legislative members and

1 Olken, B. A., \& Pande, R. (2012). Corruption in developing countries. Annu. Rev. Econ., 4(1), 479-509. 
also officials in the Ministry of Domestic Affairs. In the Prosecutors' indictment of $\mathrm{KPK}^{2}$ it was stated that from the fund it was agreed that 51 percent of the budget was spent on the project, while 49 percent would be distributed to the Ministry of Domestic Affairs, members of the House of Representatives, and the profits of executor or partners. ${ }^{3}$ The case of E-KTP is allegedly detrimental to the State finances of Rp 2.3 trillion. 4

The case at local government level, corruption involving the executive is the Head of Region. According to KPK as many as 361 regional heads in Indonesia are involved in corruption cases, consisting of 343 regents/mayors and 18 governors stumbled over corruption, so as long as local autonomy, there are $70 \%$ of regional heads is corruption. ${ }^{5}$ Corruption also involves the Penitentiary as in the case of Prodeo Hotel that was transformed into a star hotel. Corruption also affects the taxation sector, such as the case of Gayus as tax mafia that manipulates taxes against 151 tax evasion cases. This illustrates the bureaucratic and legal mafia because it is able to dump the rule of law with billions of rupiah. The case of Gayus is indeed a condition of interest, because it is allegedly or allegedly involving big businessmen and foreign companies, and also involves the authorities. 6

The case that sensation of Indonesian community was the alleged corruption perpetrated by M. Nazaruddin against the project of Athlete Building (Kemenpora Corruption Case) in Palembang that involves Angelina Sondakh, Andi Malarangeng and Anas Urbaningrum, the case illustrates that allegations of corruption have begun to shift to the body of political parties, and corruption committed by those who have power, and according to the author, this corruption is much greater affect the legal system in Indonesia.

Referring to the development of corruption cases in Indonesia that so structure and systematic, the authors see there is an increasingly systematic corruption in the law enforcement system in Indonesia and make the perpetrators not deterrent. Based on this background, this paper aims to analyze why corruption occurs systematically in the legal system in Indonesia and how the solution of Sharia Islam in efforts to eradicate corruption.

\section{Method}

This research was a normative-legal research. The approach uses statutory approach which is a legal approach related to the regulation on eradication of corruption in Indonesia. The legal materials used are primary legal materials such as legislation related to eradication and prevention of corruption. Secondary legal materials in the

2 Komisi Pemberantasan Korupsi (KPK) is the Indonesian Corruption Eradication Commission, which was formed after special consideration on the extraordinary nature of corruption in Indonesia, which has become systemic and widespread, and has violated the human rights of the Indonesian people. The KPK was formed under Act No. 30 of 2002 on the Corruption Eradication Commission.

3 Ambaranie Nadia Kemala Movanita. (2017). Inilah Daftar Mereka Yang Disebut Terima Uang Proyek E-KTP. http:// nasional. kompas.com /read/2017/03/09/16182831/ini. daftar. mereka. yang. disebut.terima.uang. proyek.e-ktp. (Accessed on 23 May 2017).

4 Nanada Perdana Putra. (2017). Daftar Nama Besar Yang Terseret Kasus E-KTP. http://news.liputan6.com/ read/2880121/daftar-nama-besar-yang-terseret-kasus-e-ktp. (Accessed on 23 May 2017).

5 Safari. (2016). KPK; 361 Kepala Daerah Terlibat Korupsi. Available online at: http://nasional. harianterbit.com/nasional/2016/08/11/67140/44/25/KPK-361-Kepala-Daerah-Terlibat-Korupsi. (Accessed on 23 May 2017).

6 Mispansyah: Kolom Opini Banjarmasin Post, February 1st, 2011. 
form of writing like dissertation, thesis or papers, articles and reports relating to corruption. Tertiary legal material is a dictionary. The legal material was collected and then compiled and found systemic corruption in the Indonesia's legal system and drawn a conclusion.

\section{Systemic Corruption in the Indonesia's Legal System}

The notion of corruption comes from the Latin "corruptive" or "corruptus", then the word corruptio comes from the word corrumpore (old Latin word). ${ }^{7}$ Further adopted in European languages such as English is "corruption", "corrupt" and in French "corruption," Dutch "korruptie". According to the Indonesian encyclopedia that corruption in Latin corruptio equals bribery; and corrumpore is as destructive as the phenomenon that officials of state bodies abuse the occurrence of bribery, counterfeiting, and other irregularities. ${ }^{8}$ If we review the dictionaries about corruption, both Indonesian-English and English-Indonesian, it will be found that the meaning of the word corruption is rotten, bad, depraved, bribable, bribed. ${ }^{9}$

Corruption is a systematized and organized crime, it is a structured crime that is very intact, entrenched, powerful and permanent in character. It is already part of the existing "system", therefore a maximum effort for law enforcement, especially the eradication of corruption must be done by a system approach, otherwise known as the "Systematic Approach."10

The problem of corruption is a problem that is very difficult to eradicate, because it is very complex. According to Barda Nawawi Arif that corruption is closely related to the complexity of other problems such as attitude, morals, lifestyle and social culture. ${ }^{11}$ Thus, corruption is closely related to the system. The term system is adopted from the Greek, systema which can be interpreted as a whole consisting of various parts that are related.12 According to Djoni S. Gozali, the legal system is a subsystem of the State system where the legal system cannot be separated from political, economic, governmental system because the legal system is a sub system of the whole system in outline. ${ }^{13}$ Likewise in the criminal law enforcement system, there are 3 (three) subsystems that influence the enforcement of criminal law, namely: First, the structural system, such as the structure of law enforcement agencies; Second, the substantial system or legal material; and Third, a cultural system that includes legal education, criminal law. ${ }^{14}$

7 Fockema Andreae. (1951) as cited in Mulyadi, L. (2007). Tindak Pidana Korupsi di Indonesia, Normatif, Teoritis, Praktik dan Masalahnya. Bandung: PT Alumni, p. 78

8 Ensiklopedia Indonesia. (1983). Jilid 4. Jakarta: Ikhtiar Baru van Hoeve dan Elsevier Publishing Project. p.1876.

9 Hamzah, A. (2005). Pemberantasan Korupsi Melalui Hukum Pidana Nasional dan Internasional. Jakarta: RajaGrafindo Persada. p.4

10 Adji, I.S. (2006). Korupsi dan Pembalikan Beban Pembuktian. Jakarta: Penerbit Kantor Pengacara dan Konsultas Hukum Prof. Oemar Seno Adji, S.H. and partner. p.1-2.

11 Arief, B.N. (2005). "Sistem Peradilan Pidana Terpadu (Integrated Criminal Justice System)". (Paper). 3 September 2005. Semarang: Fakultas Hukum Universitas Diponegoro.

12 Suherman, A.M. (2004). Pengantar Perbandingan Sistem Hukum. Jakarta: PT.RajaGrafindo Persada.p.4

13 Gozali, D.S. (2007). "Sistem dan Perkembangan Hukum Perdata". Bahan Kuliah. Banjarmasin: Program Magister Ilmu Hukum Universitas Lambung Mangkurat. p.6

14 Arief, B.N. (2004). Problem Sistem Peradilan Pidana. (Paper). Semarang: Fakultas Hukum Universitas Diponegoro.p.8 
Seeing from the legal systems theory approach of Laurence M. Friedman, states that the work of law in society is inseparable from three interrelated components. ${ }^{15}$ In building the legal system according to Friedman there are 3 (three) components: 16

1) Structure: "To begin with, the legal system has the structure of a legal system consist of elements of this kind: the number and size of courts; their jurisdiction. Structure also means how the legislature is organized what procedures the police department follow, and so on. Structure, in way, is a kind of cross section of the legal system... a kind of still photograph, with freezes the action."

2) Substance: "Another aspect of the legal system is its substance. By this is meant the actual rules, norm, and behavioral patterns of people inside the system...the stress here is on living law, not just rules in law books.

3) Culture: "The third component of legal system, of legal culture. By this we mean people's attitudes toward law and legal system their belief ... in other word, is the climate of social thought and social force which determines how law is used, avoided, or abused"

The author uses the theory of this legal system as a "knife of analysis" on the problematic of eradicating corruption in Indonesia. Let us examine why corruption is so systemic.

\subsection{The Weakness of Legal Substance}

First, seeing from the component of legal substance (the material of the legal formation) can be seen from the way of thinking in legal scholarship as well as material legislation that is made. According to the authors seen from the substantial components (legal materials) made in Indonesia, there are weaknesses and provide opportunities for corruption. Seeing from the legal framework starting from Reality $>$ Legal Facts $>$ Concepts $>$ Categories.

An event or reality can never be repeated, it is usually to reveal an event, the person compiling legal facts (data collection, evidence and others) that reinforce the allegation towards the concept of law or presumption/allegation that will move the rule of law to a person, or with the concept of law can entrap a suspect/defendant in a legal event.

However, the point of weakness or can be misused is on the determination of a case that can be referred to as a crime or not, is the stage of preparation of legal facts, so far that have authority in the preparation of legal facts are investigators (for cases of corruption, Police, Prosecutors, Corruption Eradication Commission (KPK)) so that the judicial court mafia is playing, but the police cannot work alone, because the BAP to continue in the next stage of the indictment, the judicial mafia should also play at the prosecution level i.e the Prosecutors' Office so on up to the level of court ruling even to the Penitentiary.

As an example of a lack of clarity on the development of the Century Gate case, where the Police from the beginning said there was no criminal element, and followed by the prosecutors' office, and lastly in 2011, KPK said that indeed the element was against the law, but the party entrapped only at the level of implementer is not the policy maker. Whereas Pusat Pelaporan dan Analisis Transaksi Keuangan (PPATK) found 59

15 Aswanto. (2012). Teori Hukum. Bahan Kuliah. Makassar: Program Doktor Ilmu Hukum Universitas Hasanuddin. p.10

16 Lawrence M. Friedman. (1975). The legal System, A Social Sciences Perspectie. Russel Sage Foundation. New York. 5-6. 
suspicious transactions that flowed to certain political party figures, but until now the case did not develop.

Seeing from the substance of the legislation material in Indonesia, the problem of corruption has long been pursued in the form of legislation. In 1957 made Peraturan Penguasa Militer that stipulated the term "corruption" in juridical. Peraturan Penguasa Militer dated 9 April 1957 No. Prt/PM/06/1957, then 27 May 1957 No. Prt/PM/03/1957 and 1 July 1957 No. Prt/PM/011/1957. Peraturan Penguasa Militer Pusat is valid only temporarily. ${ }^{17}$ The regulation was made because the Criminal Code was not able to cope with the widespread of corruption.

Furthermore, in the new order and reform era, legislation was created, namely: Act No.8/1974 on the Principles of Personnel; Act No. 28/1999 on the State Administration are Free and Clean of KKN; Indonesia also has Act No. 31/1999 jo. Act No. 20/2001 on Corruption Eradication; and Act No. 30/2002 on Corruption Eradication Commission. ${ }^{18}$ However, in its journey, corruption grew more and more widespread both during the Old Order and the New Order. In fact, the forerunners of the Reform Era, who had been shouting loudly to eradicate corruption, ultimately became the source of the flourishing of corruption, with various policies governing the administration of corruption, collusion and nepotism. ${ }^{19}$

Often enforcement officials play the contents of the chapter with each other, for example between Article 2 paragraph (1) and Article 3 of Act 31/1999 jo Act No.20 / 2001 (UU PTPK), provision of Article 2 paragraph (1) is wastebasket article for the perpetrators of any person, does not distinguish officials and ordinary people, while Article 3 is specific to officials or state officials. Often the judges directly apply Article 3 to the perpetrators of corruption offenses that they come from the official/ position, but the threat of minimum sanction is low i.e 1 year, while Article 2 paragraph (1) UUPTPK legal subjects anyone including officials, but the sanctions are more severe at least 4 years, whereas the qualification of the criminal act is the same that is detrimental to State economy.

Based on the author's conclusions as we have done since 2006 to 2011 about corruption cases in South Kalimantan often the judges directly apply Article 3 to the perpetrators who officials/people have a position, whereas the fulfilled element is against the law is met not an element of abuse of authority, then the average criminal verdict only a minimum of 1 year. This is the legal loophole that is often used by law enforcement officers. ${ }^{20}$

Legal products in the form of laws rather than preventing corruption, even weakening the corruption eradication itself, this is reasonable because the act is a political product made by the House of Representatives that has an interest, so that the mafia become more systematized. As an example of the issuance of Act No.46 of 2009 on Corruption Crime Trial whose contents, rather than strengthening the eradication of corruption

17 Djaja, E. (2010). Meredesain Pengadilan Tindak Pidana Korupsi, Implikasi Putusan Mahkamah Konstitusi Nomor 012-016-019/PPU-IV/2006. Jakarta: Sinar Grafika. p.30

18 Mispansyah. (2010)." Negara Tersandra Koruptor dan Mafia Hukum". Banjarmasin Post. p.26. https://issuu.com/deny_bpost/docs/bp20110201. (Accessed on 5 June 2017).

19 Azzaini, J. (2002) "KKN: Tumbuh Subur Dalam Kapitalisme". Majalah Al-Wa'ie No. 21 Tahun II, 131(05):7-8.

20 Komisi Yudisial. (2011). Penerapan dan Penemuan Hukum Dalam Putusan Hakim. Jakarta: Komisi Yudisial.p.43-52 
but it is opposite. For more details, the authors pointing out the articles that weaken the enforcement of corruption are:

First, in Article 1 letter 4 only mentions "Public prosecutor is the prosecutor as the provisions of applicable legislation". Means back to KUHAP (i.e the Attorney). The editorial in the act should refer to the special prosecution authority in the Corruption Court of the Prosecutors' Office, and now 33 Corruption Courts have been established and whose prosecute is prosecution even though the KPK can, but because of the lack of personnel, the prosecutor finally prosecutes. In 2010, in various region occurs free verdict as decided by a judge in Corruption Court, this could be because from the beginning of the investigation and compiled in the indictment by the prosecutor was weak finally the defendant is free. Second, Article 28 (1) on Wiretapping: all evidence presented in the hearing including evidence obtained from the tapping must be obtained legally in accordance with the provisions of legislation (as court permission).

Efforts to weaken the corruption eradication are also continuing. There is currently a Draft Law on Corruption Eradication that will replace Act No.31 of 1999 jo Act No. 20 of 2001. There are some provisions that instead of strengthening, but instead weakening efforts to eradicate corruption in Indonesia. Some articles that weaken the corruption eradication are: First elimination of actions that harm the State finances in Draft of Corruption Acts; Second, the absence of death penalty in certain circumstances as in Article 2 paragraph (2) of UUPTPK, the absence of such articles has implications will harm corruption eradication In Indonesia, most of which still emphasize the robbery of State assets or state finances; Third, the loss of article about State financial loss in the Draft of Corruption Acts; Fourth, the removal of minimum threats in the Draft of Corruption Acts, including embezzlement of natural disaster funds, procurement of goods and services without tendering, conflicts of interest, gratification and improper reporting of assets; Fifth, weak sanctions for mafia. In Act 31/1999 jo Act 20/2001 bribes law enforcement, threats at least 4 years and a maximum of 20 years. But in the Draft of Corruption Acts, threats at least 1 year and a maximum of 7 years plus $1 / 3$ penalty; Sixth, the elimination of additional sanction in the form of paying replacement money, whereas the regulation of replacement money that has been regulated in Act 31 of 1999 jo Act 20 of 2001; Seventh, not clearly mentioned about the prosecution authority by the KPK. Article 32 the Draft of Corruption Acts is clearly stated about the KPKs authority only until the investigation stage. "The lack of clarity in the regulation of the KPKs authority in this draft further weakens the KPKs function in entrapped the corruptors; Eighth, Article 52 of the Corruption Acts, mentioned corruption with a value not exceeding $\mathrm{Rp} 25$ million is exempt from prosecution. Its condition, the perpetrator returned the money and admitted his mistake; Ninth, criminalization of corruption case reporter as stated in Article 18 of the Draft, whereas in Article 10 Paragraph 1 of Act No. 13 of 2006 on the Protection of Witnesses and Victims, it is clear that the victim witness cannot be punished by the criminal sanction because of his report, "with this article it will castrate the public participation in eradicating corruption.

Seeing the reality above, therefore, the legal substance component in the form of legislation in government version submitted to the House of Representatives rather than eradicating corruption, but instead has done "guidance" of corruption in Indonesia. 


\subsection{Damage of Structural Sub-System}

In subsystem of legal structural, i.e institutional, currently all institutions in Indonesia no one are not exposed to the corruption virus both executive, legislative and judiciary as well as the private sector (entrepreneurs). The rise of corruption in the Regional Head Election shows that the liberal democracy system fosters the practice of 361 regional heads (governors/regents/mayors) in Indonesia involved in corruption cases. At law enforcement agencies, the investigating/police agencies, prosecuting/ prosecuting bodies, judiciary, and criminal/ penitentiary agencies are fertile ground for corruption.

The integrity of human resources of law enforcement agencies in Indonesia tends to corrupt in enforcing the law. It is a common secret of poor mentality of law enforcement apparatus or state administration in our beloved country. According to the Corruption Eradication Commission, since its establishment until January 2017 has dealt with 43 law enforcement officers are entangled in corruption cases. Of the 43 people, the most are judges as many as 15 people including one judge of the Constitutional Court. Then, 11 people are advocates, seven clerks, seven prosecutors and three policemen. ${ }^{21}$

An example, in Banjarmasin extortion committed by the former Chief of District Court Banjarmasin (S), which has only served 3 (three) months, extort the defendant of coal and dentist, there are two cases of alleged extortion. First, the alleged extortion of a dentist named Susiana Ningsih Ongkowijoyo. At that time, Susiana wanted to request the execution of land to the District Court of Banjarmasin but asked for money Rp 150 million. Second, (S) is suspected of extorting a coal businessman named Farlin Ridwansyah. Farlin, a suspect in the police was promised to be released by Sudiarto. Initially, Soediarto allegedly asked for money of Rp 10 billion, but only approved Rp 5 billion. The defendant handed over Rp 250 million and 1 car camry. But, before paying off, the case was revealed and the former Chief of District Court Banjarmasin was then tried by the court of judge honor and proposed to be discharged. ${ }^{22}$ The horrendous case happened to the former chairman of the Constitutional Court who received a bribe of 4 billion rupiah in handling disputes of Regional Election in Gunung Mas District of Central Kalimantan and Lebak Banten. These cases are only a small part of which is revealed, many still are not revealed, this is like the iceberg phenomenon.

Based on the report of Global Transparency Baromater 2017, which published by Transparency International Indonesia (TII), the public perception especially the entrepreneurs as respondents to the corruption form of bribery, that the most corrupt institution is the House of Representatives and then bureaucracy, Regional Representative, Directorate of Tax, Police, Ministry and Court. 23

21 Yustinus Paat. (2017). “KPK Telah Tangani 43 Aparat Penegak Hukum Terjerat Korupsi”. Available online at: http://www.beritasatu.com/nasional/410882-kpk-telah-tangani-43-aparat-penegak-hukum-terjeratkorupsi.html. (Accessed on 05 May 2017)

22 Irwan. (2009). "Majelis Kehormatan Hakim Usulkan Sudiarto Dipecat". https://news.detik.com/berita/d1210940/majelis-kehormatan-hakim-usulkan-sudiarto-dipecat. Accessed on 05 May 2017.

23 Rika Kurniawati. (2017). "Hasil Survei Transparaency Internasional Indonesia: DPR Lembaga Terkorup di Mata Publik." Avalaibale online at: http://www.rappler.com/indonesia/berita/163647hasil-survei-transparency-international-indonesia-dpr-lembaga-terkorup. Accessed on 05 May 2017 
Table 1. Transparency International Indonesia (TII) Report on Corruption Perceptions Index

\begin{tabular}{clcc}
\hline No & \multicolumn{1}{c}{$\begin{array}{c}\text { Institution } \\
\text { (Object) }\end{array}$} & $\begin{array}{c}\mathbf{2 0 1 3} \\
\mathbf{( \% )}\end{array}$ & $\begin{array}{c}\mathbf{2 0 1 7} \\
\mathbf{( \% )}\end{array}$ \\
\hline 1 & House of Representatives - Republic of Indonesia & 89 & 54 \\
2 & Bureaucracy & 79 & 50 \\
3 & Regional Parliament & - & 47 \\
4 & Directorate of Tax & - & 45 \\
5 & Police & 95 & 40 \\
6 & Ministries & - & 32 \\
7 & Courts & - & 32 \\
8 & Enterpreneurs & 54 & 25 \\
9 & Religion Figures & 31 & 7 \\
\hline
\end{tabular}

Source: Transparency International Indonesia, 2017

In the judicial, mafia practices occur systematically that involving all components, can be in the direction of the suspect or otherwise from law enforcement. Judicial mafia can also be through a Legal Counsel (advocate) to negotiate cases to police institutions, prosecutors, and judiciary and even to prisons. Everything has been contaminated with the practice of bribery, bribes so that the practice of judicial mafia is like a vicious circle systematized.

\subsection{Assessing from the Legal Culture Perspective}

The capitalistic legal education system and the pragmatic legal sciences have created corrupt societies, hedonistic life paradigms and the birth of a person who understands happiness is matter. ${ }^{24}$ Get the term of Rahardjo that the law was born more towards capitalist law (Oil and Gas Acts No.22/2001, Act No.25/2007 on Capital Investment, Electricity Act, Health Act, Mineral and Coal Act, Water Resources Act and others).25 Thus, the paradigm of happiness is measured by matter. Thus, graduates of the law after graduation and become a scholar instead of they improve the law but instead participate in the circle of the judicial mafia which is misguided and add corruption in Indonesia. The results of ICW's study of Makassar Branch stated that $97 \%$ of judges are naughty and only $3 \%$ are good judges.

Law graduates who understand that the law is only in the level of legalistic rules, finally gave birth to a firm apparatus against the case of Mbah Minah thief 3 cacao fruit, watermelon thief, cassava stem, for understanding legalistic criminal law that the law is in the form of texts in Acts or just understand the law in the dogmatic/legalistic level not to the level of legal philosophy. ${ }^{26}$ In the case of corruption is not a few are freely

24 Lopa, B. (1997). Masalah Korupsi dan Pemecahannya. Jakarta: Penerbit Kipas Putih Aksara. p.45-47

25 Rahardjo, S. (2006). Membedah Hukum Progresif. Kumpulan tulisan di Kompas. Jakarta: Buku Kompas. p.75

26 Sidarta, B.A. (2000). Refleksi tentang Struktur Ilmu Hukum sebuah penelitian tentang Fundasi Kefilsafatan dan Sifat Keilmuan Ilmu Hukum sebagai Dasar Landasan pengembangan Ilmu Hukum Nasional Indonesia. Bandung: Mandar Maju. pp. 115-120 
punished, or if punished, with punishment under minimum and it up to be jurisprudence in the Supreme Court. ${ }^{27}$

According to Romli Atmasasmita, ${ }^{28}$ the development of western civilization that is capitalism, also the rapid flow of information, communication and transportation and other hedonism culture has brought Indonesian society into the world scene with all its consequences. This rapid development has accelerated the process of crystallizing the creation of "materialistic characteristics," thus in turn shaping the rationalistic, materialistic personality of the Indonesian nation.

As described, it can be concluded that corruption occurs systemically in Indonesia due to the paradigm of understanding the system of life adopted by the State, namely the capitalist system; the system is built on the basis of the separation of religious arrangements with the life or called secular. So that resulted in the making of rules handed over to humans, and human tendency to make rules based on mere lust. Finally resulted in bad law system and bad people, the bad law system is the weak of substance (law material/Acts) produced precisely creating injustice, creating damage to structural subsystem (institutional component) and legal culture subsystem that is not law-abiding and materialistic society. The existing system also creates a greedy, insecure and corrupt human being. Such a man is born of a secular system of capitalist ideology. At the time of running the trust they tend to not trust, cheating and corruption, so corruption occurs systemically because the fruit of the capitalist system damage that is applied in our beloved country.

\section{Solution of Sharia Islam in Eradicate Corruption}

Having learned that the root of the problem of corruption is the result of the secular capitalist system applied in Indonesia, which understands the separation of the living systems with religious affairs. So, the solution is to understand the life system, that is from the capitalist system which is based on the making of legislation to human, replaced with the Islamic system, that is making the ideology of Islam in the regulation of human life either in the regulation of worship, economic, politics, law, education, government, and social society. The system derived from the substance of Allah Almighty.

A good legal system will create a good human being, if a good legal system is created, then anyone who runs the system, will remain good, but if the legal system is based on passions, even if run by good people, then will entrapped into crimes including corruption. This has been proven in the case of corruption in the Ministry of Religious Affairs that occurred in the corruption of the eternal funds of the people who entrapped the Minister of Religious Affairs at that time, he was known as a person who hafiz al Qur'an, as well as allegations of corruption that entrapped LHI in the case of beef imports.

27 Lestari, U.S. (2009). "Hukuman di Bawah Minimalis dalam korupsi Pasal 2 ayat (1) dan Pasal 3 UU No.31/1999 jo UU No.20/2001". (Thesis). Banjarmasin: Fakultas Hukum Universitas Lambung Mangkurat.p.40

28 Atmasasmita. R. (2002). Korupsi, good Governance dan Komisi anti Korupsi di Indonesia. Jakarta: Badan Pembangunan Hukum Nasional. p. 2 
The concept of corruption in Islam include: Ghulul (abuse of position), ${ }^{29}$ Khianat (not trust), Risywah or rashu (giving bribes). ${ }^{30}$ Corruption in Shaira Islam is called treason, the person is called khaa'in, including the embezzlement of money mandated or entrusted to a person. Theft is not categorized in corruption, because the definition of theft is to take someone property secretly. While treason is not the act of taking other peoples' property, but the act of betrayal done by someone, that is embezzling the property that is mandated to someone. ${ }^{31}$ So, corruption is a kind of deprivation of the wealth of the people and the State by utilizing the position to enrich themselves and others.

The solution of Shariah Islam in eradicating corruption, includes: First, create individual's devotion for law enforcement officers and society supported by the Islamic system both oversight by the State and the people, so as to create a law-abiding culture of its citizens; Second, a proper salary system, the officers must work as well as possible with the necessities of life and the obligation to provide for the family, in order to work quietly it must be given a decent salary and allowance. This is based on the Hadith of Rasulullah SAW from the report of Abu Dawud which means "whoever is entrusted with a job in a homeless state, shall be provided with a house, if he has not married yet, if he has no servant he shall take the servant, if he no vehicles should be given, as for whoever takes away from it, that is cheating." 32 Also, the head of State, for example the Caliph Abu Bakar was given the treasure of the Baitul Mal as compensation from business left behind when serving as Khalifah. With such pillars, a Head of State can exercise overall politics and the State can make a massive reshuffle of people who are considered corrupt.

Third, the prohibition of accepting bribes and gifts. In relation to the prohibition of bribing, Abu Daud in a hadith from Abu Hurairah r.a, that Rasulullah SAW has affirmed "Allah cursed the bribe and the recipients of bribes in power" (HR Ahmad and Abu Daud). ${ }^{33}$ Regarding a person's gift to State officials, Rasulullah SAW named with the term "ghulul" or "shuf", i.e unlawful property. Rasulullah SAW said "The gift received by the rulers is ghulul (unlawful property)" (Ahmad and al-Baihaqi). ${ }^{34}$ Bribes and gift will adversely affect the mental apparatus of law enforcers, apparatus work unfairly, in the field of justice, law enforced is unjust and tend to win the bribe party or giving gift.

Fourth, the calculation of assets and the implementation of reversing evidence system, namely the calculation of assets of officials who allegedly involved in corruption, to prove the asset acquired before and after taking office. According to the testimony of

29 Fazzan. (2015). “Korupsi di Indonesia dalam Perspektif Hukum Pidana Islam" Jurnal Ilmiah Islam Futura. 14(2): 146-165.

30 Umam, A.C. (2014). "Islam, Korupsi dan Good Governance di Negara-Negara Islam”. Jurnal Al-Ahkam Jurnal Pemikiran Hukum Islam. 24(2): 195-224

31 Al Maliki, A., and Ad -Da'ur, A. (2011). Sistem Sanksi dan Hukum Pembuktian Dalam Islam. Jakarta: Pustaka Tharikul Izzah. p.82

32 Al Jawi, M.S. (2012). "Mencabut Korupsi Sampai ke Akar-akarnya Dengan Syariah Islam.” Available online at: http:/ / hizbut-tahrir.or.id/2012/05/02/mencabut-korupsi-sampai-ke-akar-akarnya-dengansyariah-islam/. Accessed on 08 June 2017.

33 Ibid

$34 \quad$ Ibid 
Abdullah bin Umar, Caliph Umar once calculated the property or asset the regional head Sa' ad bin Abi Waqash. ${ }^{35}$ His son also did not escape Umars' shout, when he saw his sons' fat camel in the market, he confiscated it? Umar knew his camel was fat because he was herded with the camels of Baitul Mal in the best pastures. Umar also confiscated half of Abu Bakrah's wealth, the man said "I am not working for you" The Caliph replied "true, but your brother as Baitul Mal official and a share of the land in Ubullah lends you the treasure of Baitul Mal for business capital." 36 Even Umar did not underestimate embezzlement even just camel saddle. ${ }^{37}$ This is an example of the calculation of official asset before and after taking office and being held accountable for its asset and the use of a reversing evidence system has been applied in the Islam system. In connection with the corruption of abuse of power, then the asset is returned to the owner if the owner is known, or returned to the State treasury.

Fifth, exemplary leaders, stories of Caliph Omar's confiscation of the camels of his son Abdullah bin Umar, then the story of Umar bin Abdul Aziz at the beginning of his reign to clean up the family and his family and clean up things that went wrong in the government, to his wife Khalifah Umar Bin Abdul Aziz said "choose by you, you return this jewelry treasure to the Baitul Mal or let me leave you forever". ${ }^{38}$ This is proof of exemplary that can be created by the Islam system.

Sixth, equal punishment, in his nature, man is afraid of punishment for himself; the criminal purpose in Islam does serve as a penance (zawabir) recall the story of Ghamidiyah who with his own conscience admit the crime of adultery, this evidence of Islamic system can create legal awareness. Another criminal purpose is zawajir (deterrent), meaning that with the appropriate punishment of corruptors, it is hoped that people will think a thousand times to corrupt. In Islam, the corruption of sanctions is not cut off by the hand of a thief, as Rasulullah SAWT saying "the usurper, corrupt and traitor is not punished with hand-cuts", 39 but including jarimah (crime) with ta'zir, whose punishment can be tasyhir in the form of an announcement to the public is paraded around the city/now through mass media, or imprisonment until sentenced to death.

Seventh, community control; the community has a role in fertilizing or eliminating corruption. Therefore, when the devotion is created by the legal system or the legal consciousness of the society is formed, the society also plays a role in overseeing the course of Sharia Islam. Caliph Umar once asked his people to rebuke him, Umar said "if you see me deviate from the way of Islam, then straighten me even with a sword". ${ }^{0}$ With the community control over law enforcement and the running of government, corruption is difficult. Moreover, coupled with a decent salary system, bribes and gifts, the calculation of asset and the implementation of the reversing evidence system,

35 As-Suyuthi, I. (2017). Tarikh Khulafa Sejarah Penguasa Islam: Khulafa'urrasyidin, Bani Umayah, Bani Abbasiyyah. Jakarta: Pustaka Al-Kautsar. p.2740.

$36 \quad$ Al Maliki. Op.Cit., p. 277.

37 Ibid

38 As Suyuthi. Tarikh at-Khulafa.Op.Cit. p.2741.

39 HR.Ahmad, Ashabus Sunan and Ibnu Hibban

40 Ibid 
exemplary leaders, appropriate punishment, corruption can be overcome and formed a good and clean government.

Hence, the relevance of implementation independent directors' principles and good corporate governance related to the process of receivables write-off of BUMN Bank in Indonesia, desires that the enforcement of business decision making principles which is generally valid for all independent legal entity must be reinforced. Good faith, the prioritization of company necessity, good business practices, and the supported principles for the independent directors in making the decision should be supported by the government goals in order to give the complete independent towards the directors of BUMN bank related to the restriction and the settlement of bad debts which has become the burden for BUMN bank.

\section{Conclusion}

Corruption occurs systemically due to the paradigm of understanding the system of life adopted by the State i.e the capitalist system, the system is built on the basis of "fashluddin 'anil hayah", the separation of religious with the life. This resulted in the making of rules handed over to humans and the tendency of humans to make rules based on passion. Ultimately resulted in the bad law system and bad people, the bad law system is the weak of substance (legal substance) and creates injustice, bad subsystem structural (legal structure) and legal culture subsystems that are lawabiding and materialistic societies. The existing system also creates a greedy, insecure and corrupt human being. Such a man is born of a secular system of capitalist ideology. Hence, corruption occurs systemically because of the fruits of the capitalist system damage applied in Indonesia.

The solution of Sharia Islam to eradicate corruption by creating a devotion of community (law awareness) based on religious values. In addition, with a decent salary system, appropriate penalties, the implementation of reverse evidence system and the exemplary leadership, corruption problems can be overcome and a clean government can be realized.

\section{References}

Journal articles:

Azzaini, J. (2002) "KKN: Tumbuh Subur Dalam Kapitalisme". Majalah Al-Wa'ie No. 21 Tahun II, 1-31(05).

Fazzan. (2015). "Korupsi di Indonesia dalam Perspektif Hukum Pidana Islam" Jurnal Ilmiah Islam Futura. 14(2): 146-165.

Olken, B. A., \& Pande, R. (2012). Corruption in developing countries. Annu. Rev. Econ., 4(1), 479-509.

Umam, A.C. (2014). "Islam, Korupsi dan Good Governance di Negara-Negara Islam". Jurnal Al-Ahkam Jurnal Pemikiran Hukum Islam. 24(2): 195-224 
Books:

Adji, I.S. (2006). Korupsi dan Pembalikan Beban Pembuktian. Jakarta: Penerbit Kantor Pengacara dan Konsultas Hukum Prof. Oemar Seno Adji, S.H. and partner.

Al Maliki, A., and Ad -Da'ur, A. (2011). Sistem Sanksi dan Hukum Pembuktian Dalam Islam. Jakarta: Pustaka Tharikul Izzah.

As-Suyuthi, I. (2017). Tarikh Khulafa Sejarah Penguasa Islam: Khulafa'urrasyidin, Bani Umayah, Bani Abbasiyyah. Jakarta: Pustaka Al-Kautsar.

Atmasasmita. R. (2002). Korupsi, good Governance dan Komisi anti Korupsi di Indonesia. Jakarta: Badan Pembangunan Hukum Nasional.

Djaja, E. (2010). Meredesain Pengadilan Tindak Pidana Korupsi, Implikasi Putusan Mahkamah Konstitusi Nomor 012-016-019/PPU-IV/2006. Jakarta: Sinar Grafika.

Ensiklopedia Indonesia. (1983). Jilid 4. Jakarta: Ikhtiar Baru van Hoeve dan Elsevier Publishing Project.

Hamzah, A. (2005). Pemberantasan Korupsi Melalui Hukum Pidana Nasional dan Internasional. Jakarta: RajaGrafindo Persada.

Komisi Yudisial. (2011). Penerapan dan Penemuan Hukum Dalam Putusan Hakim. Jakarta: Komisi Yudisial.

Lawrence M. Friedman. (1975). The legal System, A Social Sciences Perspectie. Russel Sage Foundation. New York.

Lopa, B. (1997). Masalah Korupsi dan Pemecahannya. Jakarta: Penerbit Kipas Putih Aksara. Mulyadi, L. (2007). Tindak Pidana Korupsi di Indonesia, Normatif, Teoritis, Praktik dan Masalahnya. Bandung: PT Alumni.

Rahardjo, S. (2006). Membedah Hukum Progresif. Kumpulan tulisan di Kompas. Jakarta: Buku Kompas.

Sidarta, B.A. (2000). Refleksi tentang Struktur Ilmu Hukum sebuah penelitian tentang Fundasi Kefilsafatan dan Sifat Keilmuan Ilmu Hukum sebagai Dasar Landasan pengembangan Ilmu Hukum Nasional Indonesia. Bandung: Mandar Maju.

Suherman, A.M. (2004). Pengantar Perbandingan Sistem Hukum. Jakarta: PT. RajaGrafindo Persada.

Other sources:

Ambaranie Nadia Kemala Movanita. (2017). Inilah Daftar Mereka Yang Disebut Terima Uang Proyek E-KTP. Available online at: http://nasional.kompas.com /read/2017/03/09/16182831/ini.daftar.mereka.yang.disebut.terima.uang.proyek.e-ktp. (Accessed on 23 May 2017).

Arief, B.N. (2004). Problem Sistem Peradilan Pidana. (Paper). Semarang: Fakultas Hukum Universitas Diponegoro.

Arief, B.N. (2005). "Sistem Peradilan Pidana Terpadu (Integrated Criminal Justice System)". (Paper). 3 September 2005. Semarang: Fakultas Hukum Universitas Diponegoro.

Aswanto. (2012). Teori Hukum. Bahan Kuliah. Makassar: Program Doktor Ilmu Hukum Universitas Hasanuddin.

Gozali, D.S. (2007). "Sistem dan Perkembangan Hukum Perdata". Bahan Kuliah. Banjarmasin: Program Magister Ilmu Hukum Universitas Lambung Mangkurat.

Irwan. (2009). "Majelis Kehormatan Hakim Usulkan Sudiarto Dipecat". https://news.detik.com/berita/d-1210940/majelis-kehormatan-hakim-usulkan-sudiartodipecat. Accessed on 05 May 2017.

Lestari, U.S. (2009). "Hukuman di Bawah Minimalis dalam korupsi Pasal 2 ayat (1) dan Pasal 3 UU No.31/1999 jo UU No.20/2001". (Thesis). Banjarmasin: Fakultas Hukum Universitas Lambung Mangkurat. 
M. Siddiq Al Jawi. (2012). “Mencabut Korupsi Sampai Keakar-akarnya Dengan Syariah Islam." Available online at: http://hizbut-tahrir.or.id/2012/05/02/mencabut-korupsisampai-ke-akar-akarnya-dengan-syariah-islam/. Accessed on 08 June 2017.

Mispansyah: Kolom Opini Banjarmasin Post, February 1st, 2011.

Mispansyah. (2010). "Negara Tersandra Koruptor dan Mafia Hukum". Banjarmasin Post. hlm.26. https://issuu.com/deny_bpost/docs/bp20110201. (Accessed on 5 June 2017).

Nanada Perdana Putra. (2017). Daftar Nama Besar Yang Terseret Kasus E-KTP. http://news.liputan6.com/read/2880121/daftar-nama-besar-yang-terseret-kasus-e-ktp. (Accessed on 23 May 2017).

Rika Kurniawati. (2017). "Hasil Survei Transparaency Internasional Indonesia: DPR Lembaga Terkorup di Mata Publik." Avalaibale online at: http://www.rappler.com/indonesia/berita/163647-hasil-survei-transparency-international -indonesia-dpr-lembaga-terkorup. (Accessed on 05 May 2017)

Safari. (2016). KPK; 361 Kepala Daerah Terlibat Korupsi. http://nasional.harianterbit.com/ nasional/2016/08/11/67140/44/25/KPK-361-Kepala-Daerah-Terlibat-Korupsi. (Accessed on 23 May 2017).

Yustinus Paat. (2017). "KPK Telah Tangani 43 Aparat Penegak Hukum Terjerat Korupsi". Available online at: http://www.beritasatu.com/nasional/410882-kpk-telahtangani-43-aparat-penegak-hukum-terjerat-korupsi.html. (Accessed on 05 May 2017). 